\title{
Tsyhanov Oleh,
}

Doctor of Juridical Sciences, Docent,

Chief Researcher of the State Research

Institute MIA Ukraine, Kyiv, Ukraine

ORCID ID 0000-0002-8924-1139

\section{MONITORING OF SERVICE ACTIVITIES AND PECULIARITIES OF THEIR IMPLEMENTATION IN THE FIELD OF PUBLIC ADMINISTRATION}

The research paper is devoted to revealing the essence of monitoring of service activity and features of its implementation in the field of public administration. Monitoring in the field of public administration is defined as a system of continuous observation of the most important current results, conditions and parameters of the development of public administration in the context of its individual segments for the purpose of adjustment and forecasting. Implementation of monitoring in the field of public administration is the information support of the latter in various fields of activity, including in the sphere of service activity of administrative bodies.

The purpose of monitoring of the provision of public services is to ensure a systematic observation of the provider of these services and other interested persons in the procedure of their provision, as well as information and analytical support for decisionmaking regarding the legal, organizational and methodological support of the effective and high-quality functioning of the system of provision of public services.

The peculiarities of the functioning of the monitoring system of public service activity are investigated. Considering that system, it should be mentioned that public services are determined by the organization of provision, quality and availability, and are characterized by a set of quantitative and qualitative parameters allowing to measure, take into account, control and evaluate the results of such services.

The review of organizational and methodological, accounting and statistical, sociological, analytical, forecasting and informational subsystems of monitoring of public-service activity is distinguished and carried out. For the foundation of the 
monitoring system, it is suggested to distinguish organizational, research, analytical, reporting, information and final stages. The directions of the use of monitoring results as a tool for quality assurance and accessibility of public services are identified.

Keywords: monitoring, public administration, public service activities, public services, monitoring system of public services provision.

\section{REFERENCES}

1. Velykyi tlumachnyi slovnyk suchasnoi ukrainskoi movy. "A large explanatory dictionary of modern Ukrainian" / text. and goal. ed. V.T. Busel; 250 thousand words. Kyiv-Irpin, 2005. 1728 p. [in Ukrainian].

2. Churina L.A. (2002) Monitoring uchebnoy deyatelnosti v innovatsionnom obrazovatelnom uchrezhdenii kak faktor refleksivnogo upravleniya. "Monitoring of educational activities in an innovative educational institution as a factor of reflexive management": diss. Ph.D: 13.00.01. Moscow, 2002.155 p. [in Russian].

3. Samozhenkov V.M. (2001). Monitoring i upravlenie investitsionnyim protsessom na promyishlennyih predpriyatiyah. "Monitoring and management of investment process at industrial enterprises": diss. ... Cand. Econom. Sciences: 08.00.05. Kislovodsk. 145 p. [in Russian].

4. Nedelko S.I., Ostashkov A.V., Matyukin S.V. i dr. (2008). Monitoring v sisteme okazaniya gosudarstvennyih i munitsipalnyih uslug kak instrument realizatsii strategii povyisheniya kachestva gosudarstvennogo i munitsipalnogo. "Monitoring in the system of providing state and municipal services as a tool for implementing the strategy to improve the quality of state and municipal administration" / under total. ed. V.V. Markina, A.V. Ostashkova. Moscow: Publishers Exclibris Press, 2008.332 p. [in Russian].

5. Yedharova I.V. (2011). Monitorynh diialnosti derzhavnykh sluzhbovtsiv z nadannia publichnykh posluh: pidkhody do vyznachennia sutnosti. Derzhavne upravlinnia: teoriia ta praktyka. "Monitoring the performance of public servants in public service delivery: approaches to defining nature. Public administration: theory and practice": elect. Sciences. profession. view. No. 2. URL: 
http://academy.gov.ua/ej/ej14/txts/Edgarova.pdf (date of application: 16.11.2018) [in Ukrainian].

6. Natsionalnyi standart Ukrainy. DSTU ISO 9000-2001 (Systemy upravlinnia yakistiu. Osnovni polozhennia ta slovnyk). "National standard of Ukraine. DSTU ISO 9000-2001 (Quality Management Systems. Basics and Vocabulary)”. Kyiv: State Enterprise "Ukr SIC", 2016. 51 p. [in Ukrainian].

7. Kulemin N.A. (2001). Kvalimetricheskiy monitoring v sisteme obrazovaniya. "Qualimetric monitoring in the education system". Pedagogy. No. 3. P. 16-20. [in Russian].

8. Slivak A.Ie., Deshko A.I. (2012). Metodychni pidkhody shchodo stvorennia systemy monitorynhu nadannia administratyvnykh posluh tsentralnymy ta mistsevymy orhanamy vykonavchoi vlady. "Methodical approaches to the creation of a monitoring system for the provision of administrative services to central and local executive authorities". Formation of market relations in Ukraine. No.5. P. 64-68. URL: http://nbuv.gov.ua/UJRN/frvu_2012_5_16 (date of application: 14.08.2018) [in Ukrainian].

9. Babinova O. Problemy otsinky yakosti ta efektyvnosti diialnosti orhaniv mistsevoi vlady. "Problems of assessing the quality performance of local government bodies" URL: http://www.niss.gov.ua/Monitor/September/6.htm (date of application: 14.08.2013) [in Ukrainian].

10. Holosnichenko I.P., Tsyhanov O.H., Popova O.O. ta in. (2015). Administratyvni posluhy u sferi vnutrishnikh sprav: monohrafiia. "Administrative services in the sphere of internal affairs: monograph" / ed. I.P. Holosnichenko, O.H. Tsyhanova. Kyiv: NTUU "KPI". 590p. URL: http://ela.kpi.ua/handle/123456789/11974 (date of application: 04.12.2017) [in Ukrainian].

11. Azhazha M.A. (2012). Monitorynh yak instrument zabezpechennia yakosti derzhavnykh ta munitsypalnykh posluh. "Monitoring as a tool for quality assurance of state and municipal services". Humanities Bulletin of Zaporizhzhia State Engineering Academy".

Iss.

50.

P.

$270-277$.

URL: 
http://nbuv.gov.ua/UJRN/znpgvzdia_2012_50_30 (date of application: 16.11.2018) [in Ukrainian].

12. Brychuk K.H. (2014). Instrumentarii otsinky rezultatyvnosti diialnosti orhaniv vlady u sferi nadannia derzhavnykh posluh. "Toolkit for assessing the performance of public authorities in the provision of public services". Scientific Bulletin of the Academy of Municipal Administration. Management" series. Issue. 1. P. 224-231. [in Ukrainian]. 